\title{
Enhanced apoptotic cell death of renal epithelial cells in mice lacking transcription factor AP-2B
}

\author{
Markus Moser, ${ }^{1}$ Armin Pscherer, ${ }^{1}$ Christina Roth, ${ }^{1}$ Jutta Becker, ${ }^{2}$ Gabi Mücher, ${ }^{2}$ Klaus Zerres, ${ }^{2}$ \\ Christa Dixkens, ${ }^{3}$ Joachim Weis, ${ }^{4}$ Lisa Guay-Woodford, ${ }^{5}$ Reinhard Buettner, ${ }^{1,7}$ and \\ Reinhard Fässler 6

\begin{abstract}
${ }^{1}$ Institute for Pathology, University of Regensburg M edical School, D-93042 Regensburg, Germany; ${ }^{2}$ Institute for Human Genetics, University of Bonn, D-53111 Bonn, Germany; ${ }^{3}$ Department of Medical Genetics, University of UIm, D-89069 Aachen, Germany; ${ }^{5}$ Departments of M edicine and Pediatrics, University of Alabama, Birmingham, Alabama 35294 USA; ${ }^{6} \mathrm{M}$ ax-Planck-Institute for Biochemistry, D-82152 M artinsried, Germany
\end{abstract} \\ UIm, Germany; ${ }^{4}$ Institute for N europathology, Rheinisch Westfaelische Technische Hochschule (RWTH) Aachen, D-52057
}

\begin{abstract}
Expression of AP-2 transcription factors has been detected previously in embryonic renal tissues. We show here that AP-2 $\beta-1-$ mice complete embryonic development and die at postnatal days 1 and 2 because of polycystic kidney disease Analyses of kidney development revealed that induction of epithelial conversion, mesenchyme condensation, and further glomerular and tubular differentiation occur normally in

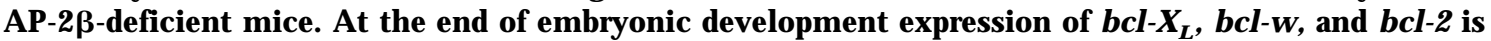
down-regulated in paral lel to massive apoptotic death of collecting duct and distal tubular epithelia Addressing the molecular mechanism we show that transfection of AP-2 into cell lines in vitro strongly suppresses c-myc-induced apoptosis pointing to a function of AP-2 in programming cell survival during embryogenesis. The position of the human A P-2 $\beta$ gene was identified at chromosome 6p12-p21.1, within a region that has been mapped for autosomal recessive polycystic kidney disease (ARPKD). Sequence analyses of ARPKD patients and linkage analyses using intragenic pol ymorphic markers indicate that the AP-2 $\beta$ gene is located in close proximity to but distinct from the ARPKD gene.
\end{abstract}

[Key Words: AP-2 $\beta$; gene targeting; apoptosis; c-myc; ARPKD]

Received February 17, 1997; revised version accepted June 13, 1997.

Three different isoforms of AP-2 transcription factors, AP- $2 \alpha, \mathrm{AP}-2 \beta$, and AP- $2 \gamma$ (the latter has been also referred to as AP-2.2) have been identified (Williams et al. 1988; Moser et al. 1995; Oulad-Abdel ghani et al. 1996). The respective proteins are transcribed from three different genes and reveal a unique modular structure consisting of an amino-terminal proline and glutamine-rich transcriptional activation domain and a complex helixspan-helix motif necessary and sufficient for homodimerization and site-specific DNA binding (Williams and Tjian 1991a,b).

All three genes are coexpressed strongly in early premigratory and migrating neural crest cells. Distinct but partially overlapping expression patterns become evident after 10 days postcoitum (dpc) and throughout later gestational stages. In the anterior neural tube AP- $2 \gamma$ is

${ }^{7}$ Corresponding author.

E-MAIL reinhart.buettner@klinik.uni-regensburg.de; FAX (49) 941-9446602. expressed exclusively in the forebrain, AP-2 $\beta$ in the midbrain, and both AP- $2 \alpha$ and AP- $2 \beta$ in the hindbrain. AP-2 expression has been detected in many tissues in the central and peripheral nervous system as well as in limb buds, epidermal, facial and urogenital tissues (Mitchell et al. 1991; Chazaud et al. 1996; Moser et al. 1997). In particular, AP- $2 \alpha$ is expressed in proximal tubular kidney epithelial cells, AP- $2 \beta$ in distal tubular epithelial cells, and AP- $2 \gamma$ in the genital bud (Moser et al. 1997). In kidney, AP- $2 \alpha$ but not AP- $2 \beta$ expression is down-regulated after birth, suggesting that AP- $2 \beta$ may be required continuously in renal epithelia.

In this study we have mutated the murine $A P-2 \beta$ gene and describe that AP- $2 \beta-1-$ mice die postnatally be cause of fulminant apoptosis of epithelial cells in collecting ducts and distal tubuli. When cotransfected with c-myc, both AP- $2 \alpha$ and AP- $2 \beta$ are capable of suppressing myc-induced apopototic cell death. These results establish a novel role for AP-2 in regulating apoptotic cell death and establish a function of $A P-2 \beta$ in survival and 
maintainance of collecting duct and tubular epithelial cells. Kidneys of AP- $2 \beta-1-$ mice develop small cysts in the renal medulla and paracortical region resembling renal cysts in autosomal recessive polycystic kidney disease (ARPKD). Although the AP- $2 \beta$ null phenotype shows some features of ARPKD and the gene is closely linked to the ARPKD locus, we did not detect AP- $2 \beta$ mutations in ARPKD patients.

\section{Results}

Genomic structure of the AP- $2 \beta$ gene

Previously, we have described the isolation of two overlapping $\lambda$ phages partially spanning the human AP-2 $\beta$ gene (Moser et al. 1995). Two further recombinant phages were isolated that harbor the $5^{\prime}$ and $3^{\prime}$ gene ends. The continuous 32.5-kb sequence covering all seven exons and six introns was obtained and submitted to the EMBL data library (Fig. 1A; accession no. Y09912). A comparison of the human AP- $2 \beta$ and the human AP- $2 \alpha$ sequence (Bauer et al. 1994) reveals that the gene structure and size of all seven exons are highly conserved, suggesting that the two genes are derived by a duplication of a common ancestral gene.

Establishment of AP-2 $\beta$-deficient mice

To generate a murine AP- $2 \beta$ null mutation we further screened a SVJ129 library and isolated a 10-kb clone spanning exons 3-5 of the murine gene (Fig. 1B). A phosphoglycerokinase (PKG)-neo selection cassette was inserted into exon 4 of the murine gene, a region of AP- $2 \beta$, which is essential for DNA binding and dimerization (Williams and Tjian 1991a). The targeting vector was electroporated into R 1 embryonic stem (ES) cells. G418resistant colonies (360) were assessed by Southern bl ot analysis for the wild-type 13-kb EcoRI and the neo-disrupted $8.5-\mathrm{kb}$ EcoRI fragments. Of the 360 col onies 6 had integrated the targeting vector by homologous recombination; clones 27 and 176 shown in Figure 2A were injected into C57B6 blastocysts for generating germ-line chimeras. Heterozygous offspring of the chimeras were normal and fertile. Representative Southern blot and PCR analyses of genomic DNA obtained from tail biopsies of wild-type, heterozygous, and homozygous mutant mice are shown in Figure 2B.

\section{Mice lacking AP-2 $\beta$ devel op polycystic kidneys}

Mating mice heterozygous for the AP- $2 \beta$ mutation produced offspring with the expected Mendelian frequency (Fig. 2B). N ewborns homozygous for the mutation had no apparent external malformation upon inspection. More than half of the AP-2 $\beta-1$-newborns, however, di ed after birth and were cannibalized by their mothers (Table 1 ). The remaining AP-2 $\beta-1-$ animals died within the first $24 \mathrm{hr}$ after birth.

A

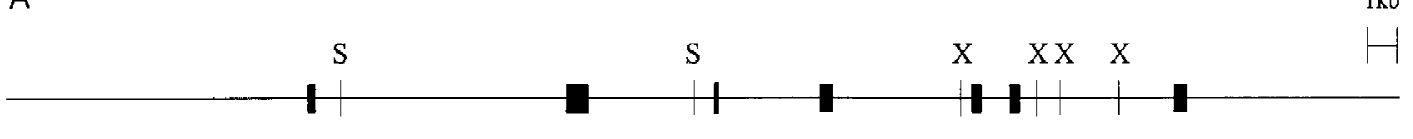

$\begin{array}{llllll}\text { Exon } 1 & \text { Exon } 2 & \text { Exon } 3 & \text { Exon } 4 & \text { Exon } 5 \text { Exon } 6 & \text { Exon } 7\end{array}$

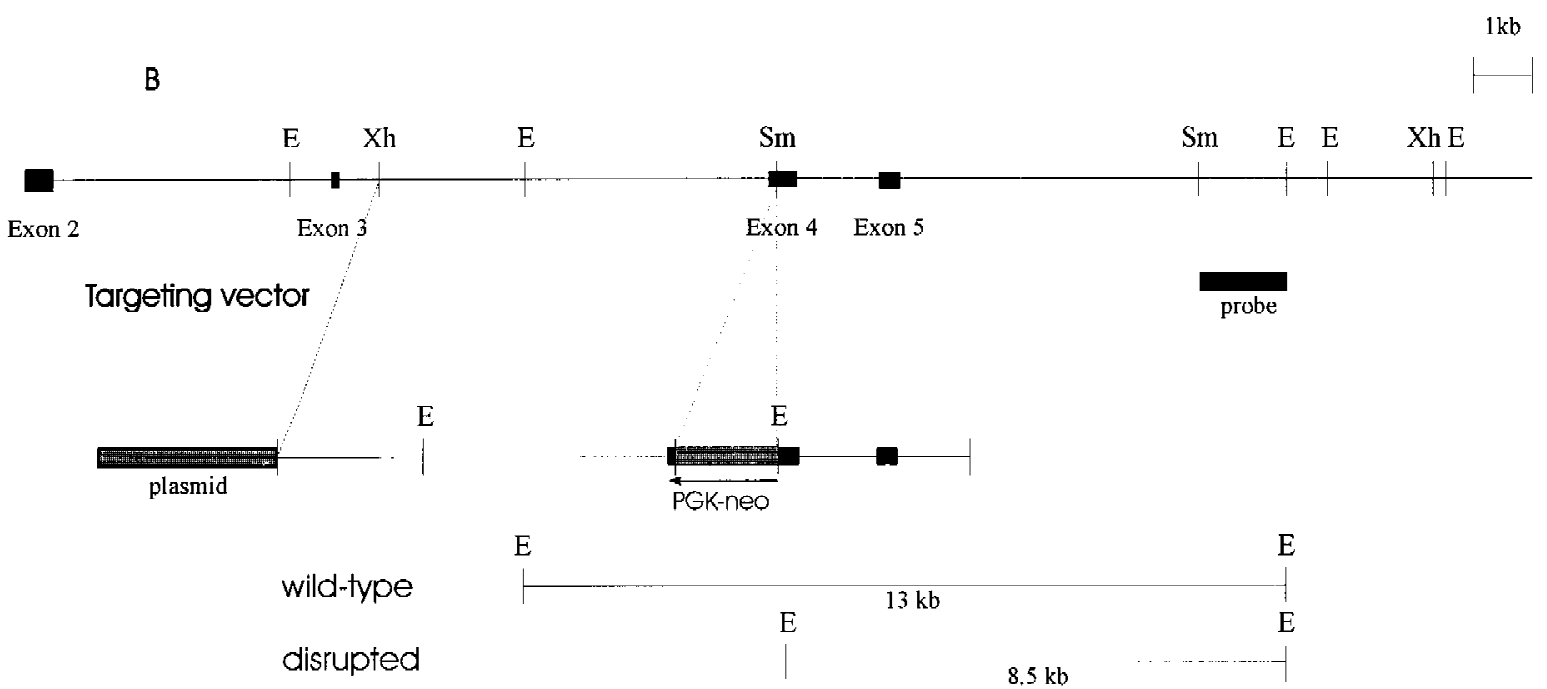

Figure 1. Structure of the AP-2 $\beta$ gene and targeting vector. (A) The structure of the human AP-2 $\beta$ gene. Boxes represent exons. (X) Xbal; (S) Sall. (B) The partial structure of the murine AP- $2 \beta$ gene is displayed above the AP-2 $\beta$ target vector. The PGK-neo cassette was inserted into exon 4, and the probe used for Southern blot analysis is indicated as a solid box. (E) EcoRI; (Sm) Smal; (Xh) Xhol. 

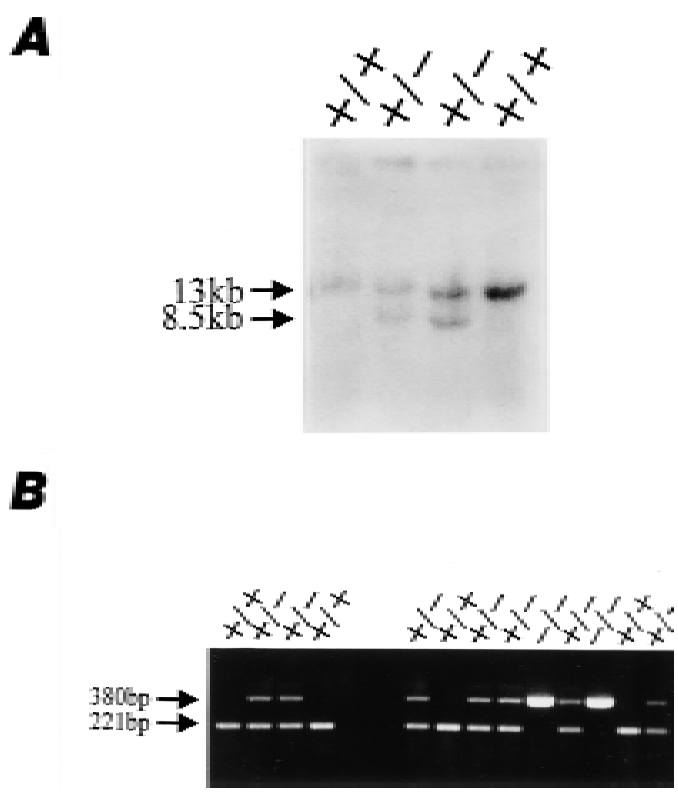

Figure 2. Generation of AP-2 $\beta$ mutant mice. (A) Southern blot analysis of two wild-type $(t+)$ and two mutant $(t-)$ RI ES cells. Shown are the two different mutant clones (27 and 176) that were used for blastocyst injection. (B) PCR analysis of the same four ES cell clones (four lanes at left) and of tail biopsy DNA from progeny of mating heterozygotes (nine lanes at right). A 221-bp fragment of the wild-type allele and a 380-bp fragment of the mutant allele were amplified using the primers described in Materials and M ethods.

The null mutation in the AP- $2 \beta$ gene was confirmed by N orthern and Western blots of midbrain extracts from wild-type, heterozygous, and homozygous animals. The midbrain was analyzed because it has been shown previously that high levels of AP-2 2 , but not AP- $2 \alpha$ and AP- $2 \gamma$ mRNA are expressed in this regi on (Chazaud et al. 1996; M oser et al. 1997). As shown in Figure 3, A and B, reduced levels of both AP- $2 \beta$ mRNA and protein in heterozygotes were detected in AP- $2 \beta-1-$ mice but no signal was found. Thus, AP- $2 \beta$ mRNA and protein are absent in the homozygous mutants.

$N$ ext, we dissected AP- $2 \beta-1-$ mice and looked for internal malformations. Macroscopically, all internal organs were normal; however, the kidneys appeared slightly smaller. Microscopically, numerous small cysts in the collecting duct system and distal tubuli were present in the kidneys of AP-2 $\beta$-deficient mice (Fig. 4A-C).

Table 1. Genotype of litter from mating AP- $2 \beta+/-$ mice at E18.5 and after birth at $1 \mathrm{dpn}$

\begin{tabular}{lrr}
\hline & \multicolumn{2}{c}{ Mice } \\
\cline { 2 - 3 } & \multicolumn{1}{c}{ E18.5 } & newborn \\
\hline$H+$ & $50(22 \%)$ & $100(31 \%)$ \\
$H-$ & $128(57 \%)$ & $194(60 \%)$ \\
$H-$ & $48(21 \%)$ & $30(9 \%)$ \\
\hline
\end{tabular}
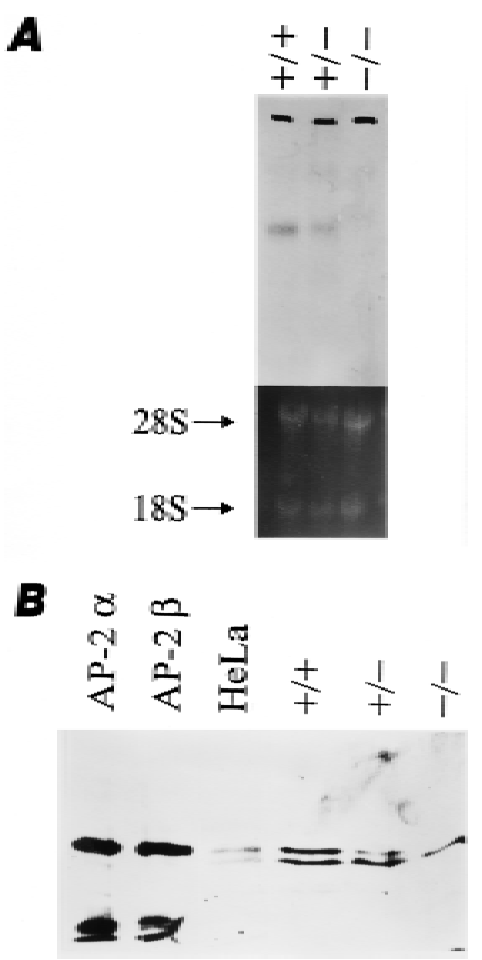

Figure 3. AP-2 $\beta$ expression in wild-type and mutant mice. (A) $N$ orthern blot analysis of midbrain lysates. The $6-k b$ AP- $2 \beta$ mRN $A$ is reduced in heterozygous and absent in homozygous mutants. (B) Immunoblot analysis of in vitro-translated AP- $2 \alpha$, AP- $2 \beta$, HeLa cell nuclear extracts, and $+t+,+-$, and $-1-$ mice with a polyclonal AP-2 antiserum. The upper specific band is reduced in $+1-$ mice and absent in $-1-$ mice. The lower band results from a nonspecific immunoreaction, as it is detected also in AP-2-negative HepG2 cells (data not shown).

The size of these cysts varied between 2- and 15-fold of the diameter of distal tubuli. Interestingly, the gross anatomic structure of AP-2 $\beta-1-$ kidneys showed a normal ureter, a renal pelvis, and a normal nephrogenic zone. Furthermore, the AP- $2 \beta$ mutation did not affect cortical structures such as glomeruli and proximal tubuli. Thorough histological examination of serial tissue sections did not reveal abnormalities in any organ other than the kidney.

To determine when cysts develop during embryonic nephrogenesis, kidneys of AP-2 $\beta-1-$ mice were analyzed at various points in time. At $15.5 \mathrm{dpc}$, kidneys of AP-2 $\beta$ $\dashv-$ mice were morphologically indistinguishable from kidneys of wild-type littermates. A pproximately two- to threefold dilated distal tubuli and collecting ducts were first detected at $16.5 \mathrm{dpc}$ (data not shown). A small number of cysts, as shown in Figure 4A, were present in stage E18.5 animals, but only kidneys from animals at birth reveal ed the complete phenotype with numerous small cysts (Fig. 4B,C). These findings clearly indicate that renal malformations in AP- $2 \beta$-null mice occur at a late stage of kidney devel opment after completion of ureteric bud sprouting, induction of epithelial conversion, and differentiation of glomeruli. 

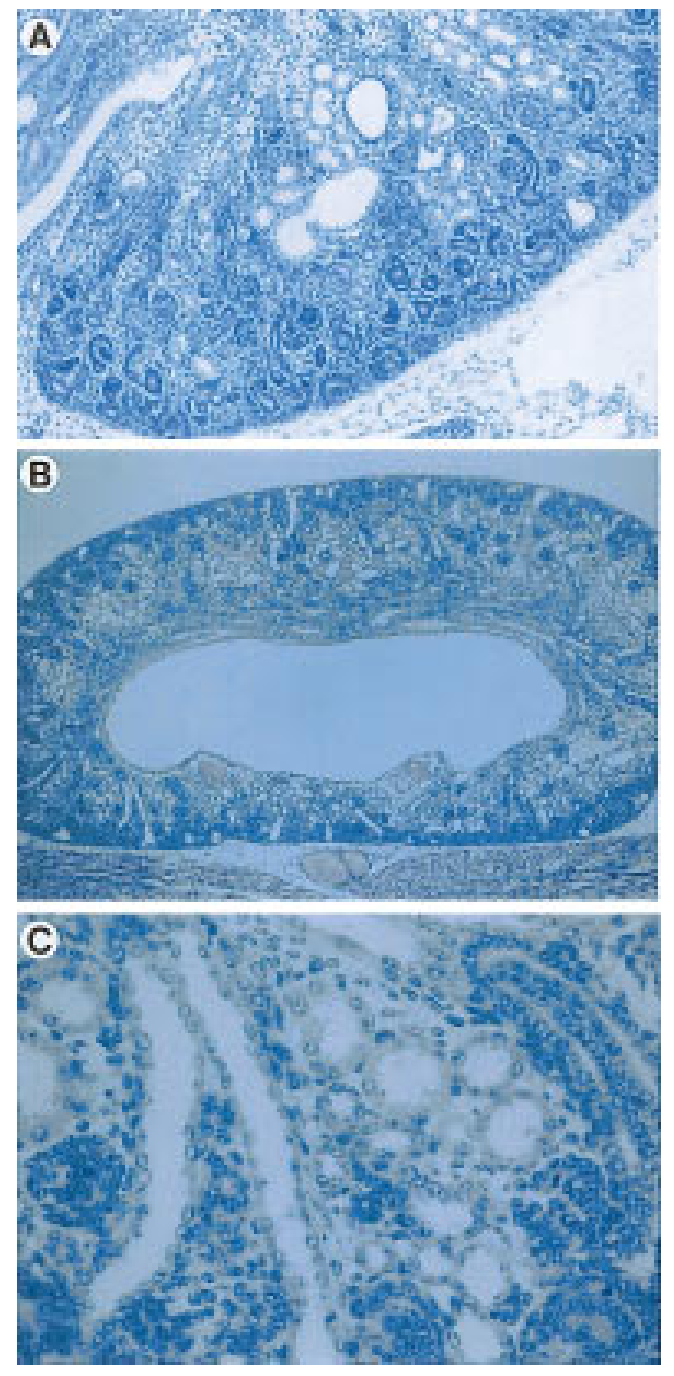

Figure 4. Histological examination of kidneys in AP- $2 \beta-1-$ mice. (A) Kidneys at E18.5 reveal a small number of cysts primarily in the area of distal tubuli (Magnification, 20x staining, hematoxylin and eosin $(H \& E)$. (B,C) Kidneys of newborn AP-2 $\beta$ $-1-$ mice. At low magnification ( $B, 20 \times$ staining, $H \& E$ ) there is a substantial reduction of cells in the renal medulla, whereas the outer nephrogenic zone in the renal cortex appears normal. Higher magnification (C, 200x) shows numerous small cysts in the area of distal tubuli and collecting ducts.

\section{Enhanced apoptosis in AP-2 $\beta-1-$ kidneys}

Detailed analysis of epithelia located within the renal cysts of A P- $2 \beta-1-$ mice and in tubuli between the cysts frequently showed nuclear pyknosis indicative of apoptotic death. Therefore, we performed TUN EL stainings of fragmented nuclear DNA and counted labeled nuclei in AP- $2 \beta-1-$ and AP- $2 \beta+1+$ mice between embryonic day 13.5 (E13.5) and 1 postnatal day (pnd) (Fig. 5). Between stages E13.5 and E18.5 the rate of TU N EL-positive nuclei in AP-2 $\beta-1-$ kidneys was slightly enhanced (less than twofold) as compared to wild-type animals. In contrast, the rate of apoptotic death was increased eightfold in the kidneys of AP- $2 \beta$ mutant mice at birth, revealing a massive wave of cell death occuring at the end of embryonic development (Fig. 6A,B). As an internal control, we measured the frequency of apoptotic cell death in the spinal cord of both mutant and wild-type animals (frequency was not altered in the mutant mice; Fig. 6A). In kidneys of wild-type animals (Fig. 5A) a normal pattern of fragmented nuclear DNA was detected in the nephrogenic zone and in the medullary papilla overlapping pre-
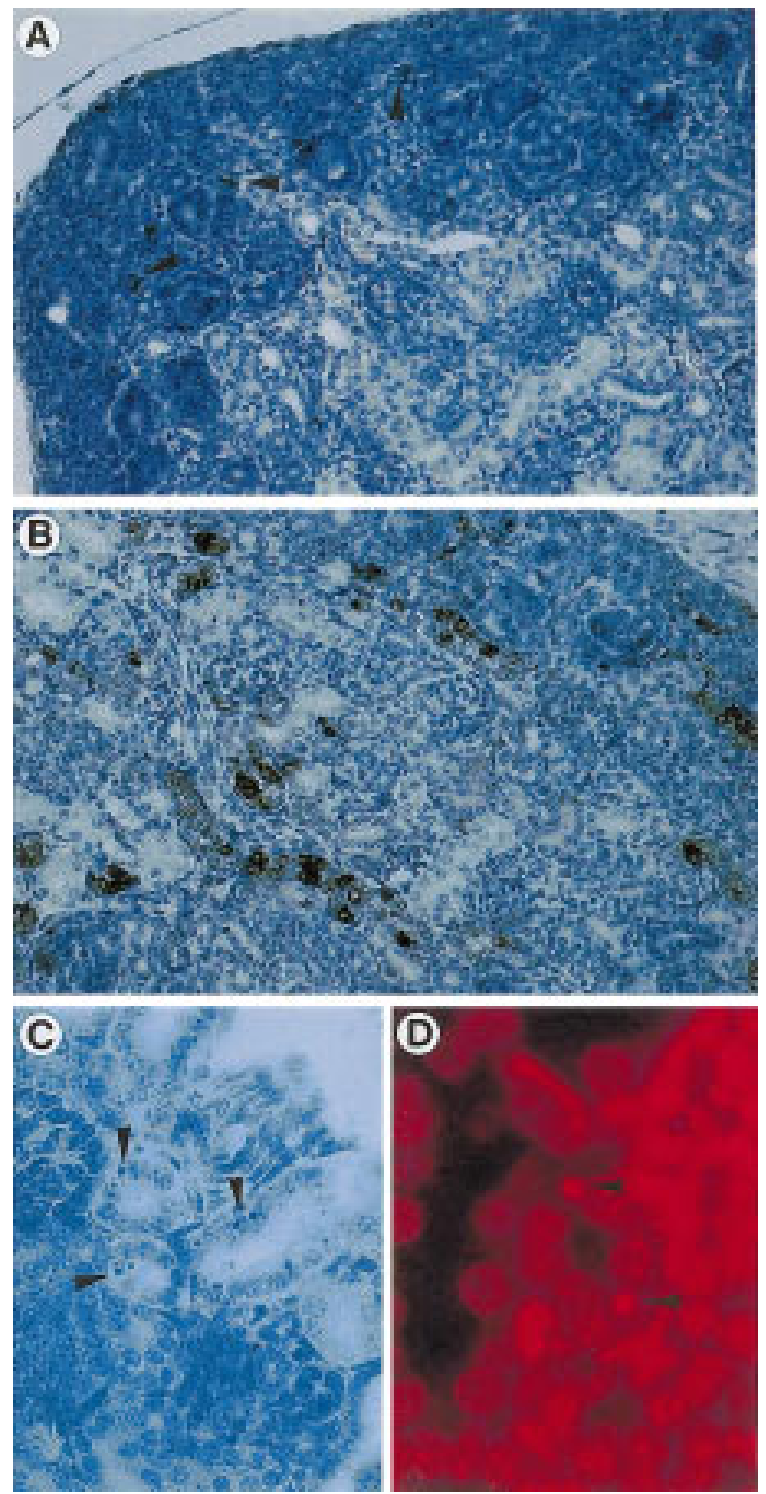

Figure 5. Detection of apoptosis in kidneys from wild-type ( $H$ $+)$ and AP-2 $\beta$ mutant $(-1-$ mice. $(A, B)$ TUNEL staining of kidneys from wild-type (A) and mutant $(B)$ mice (magnification, 20x counterstained with hemalaun). Arrowheads in A indicate few TUNEL-positive cells in the nephrogenic region, whereas numerous cells are stained in the distal tubuli and collecting ducts in B. (C,D) N uclear fragmentation in epithelial cells from -1 -mice [magnification 200x (C) H\&E; (D) propidium iodide staining]. 

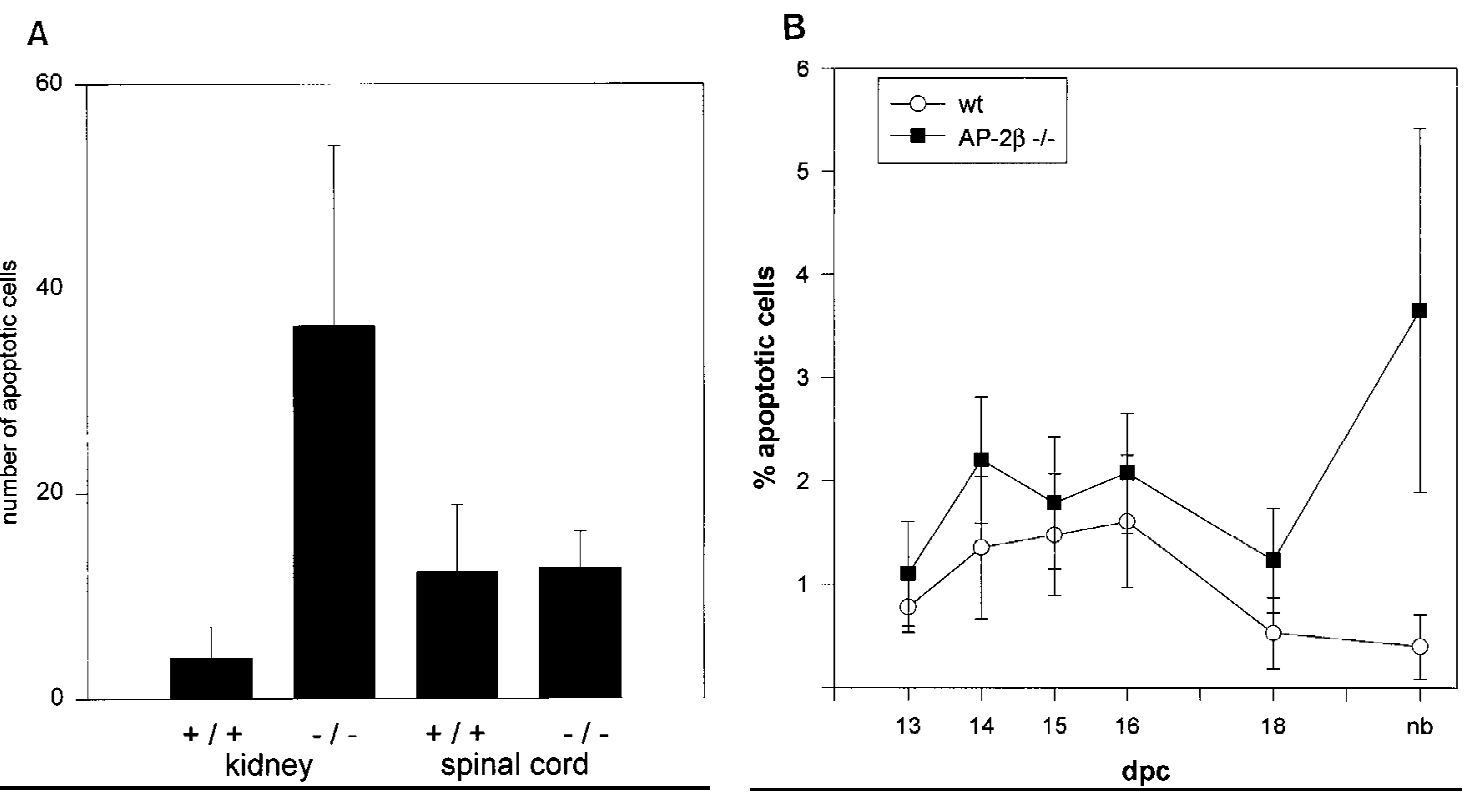

Figure 6. (A) A poptotic death ratio of renal epithelial cells and of spinal cord cells comparing wild-type $(+t+)$ and mutant $(-t \rightarrow$ mice. (B) Time course of apoptosis in the kidneys of wild-type $(+t+)$ and mutant $(-t-)$ mice during E13.5 and birth. Shown are TUN EL-stained nuclei per 1000 cells in three independent kidney sections.

cisely with the regions that have been characterized previously in normal kidney development (Coles et al. 1993). In comparison with this wild-type pattern we observed apoptotic cells in mutant mice, particularly in collecting ducts and distal tubuli (Fig. 5B,C). Further microscopic analyses of propidium iodide-stained sections indicated that the majority of TUNEL-Iabeled nuclei were fragmented (Fig. 5D). We al so measured the rate of cell division by BrdU incorporation, which was identical in wild-type and AP- $2 \beta-1$-animals (data not shown).

To determine whether the enhanced apoptotic cell death rate per se could account for the formation of renal cysts, we analyzed the expression of genes that have been linked to specific steps of renal development. In situ hybridization of embryos at gestational ages 13.5 and $15.5 \mathrm{dpc}$ was performed with WT-1, pax-2, pax-8, wnt-4, AP- $2 \alpha$, and AP- $2 \beta$ riboprobes (summarized in Fig. 7A). WT-1 signals were detected over the induced mesenchyme, wnt-4 in condensing kidney mesenchyme and developing comma- and S-shaped bodies, and pax-2 and pax-8 in developing tubular structures. Comparing hybridization signals between wild-type and mutant mice revealed identical patterns of gene expression. As reported recently, AP- $2 \alpha$ signals were confined to the area of developing proximal tubuli in the cortical zone at 15.5 dpc (Moser et al. 1997). AP-2 $\beta$ signals were detected in developing distal tubuli in wild-type animals but absent in AP-2 $\beta$-mutants. These results indicate that aggregation and proliferation of mesenchyme, as well as induction of epithelial to mesenchymal conversion, occurs normally in AP-2 $\beta$-deficient mice.

$\mathrm{N}$ ext, we determined the expression pattern of proand antiapoptotic genes in kidneys of AP- $2 \beta$ mutant mice in comparison to wild-type and heterozygous animals. We chose to analyze RN A from kidneys at E18.5 because this stage of development precedes a massive rise in apoptotic cell death based on our TUNEL stains (Fig. 6B). Thirty cycles of RT-PCR were performed, using template RN A obtained from microdissected kidneys of two wild-type, heterozygous, and mutant animals, respectively. Results shown in Figure 7B reveal that the expression of proapoptotic genes, fas, bad, bax, and myc, was identical in the kidneys of these animals, but a significant decrease of the antiapoptotic genes $b c l-X_{L}$, bcl$w$, and bcl-2 was observed. At 32 cycles the decrease of bcl-2 expression in kidneys of AP- $2 \beta-1-$ mice as compared to wild-type mice was detected even more clearly (data not shown).

In summary, our analyses define a key role of AP- $2 \beta$ for maintenance of renal epithelia in distal tubuli and collecting ducts. At the end of embryonic development a decrease in expression of the antiapoptotic genes bcl- $X_{L}$, $\mathrm{bcl}-\mathrm{w}$, and bcl-2 precedes induction of massive apoptotic cell death. In parallel, severe cystic transformation of the renal medulla occurs.

Negative regulation of myc-induced apoptosis by AP-2

To address whether AP-2 transcription factors can modulate apoptosis directly we tested the effect of AP-2 on the c-myc-induced cell death program when cotransfected into cell lines in vitro. We chose to analyze the embryonic cell line PA-1 clone 1 because these cel Is express extremely low levels of AP-2 (Kannan et al. 1994) and harbor wild-type endogenous myc genes without any mutation or amplification. Using a cytomegal ovirus 

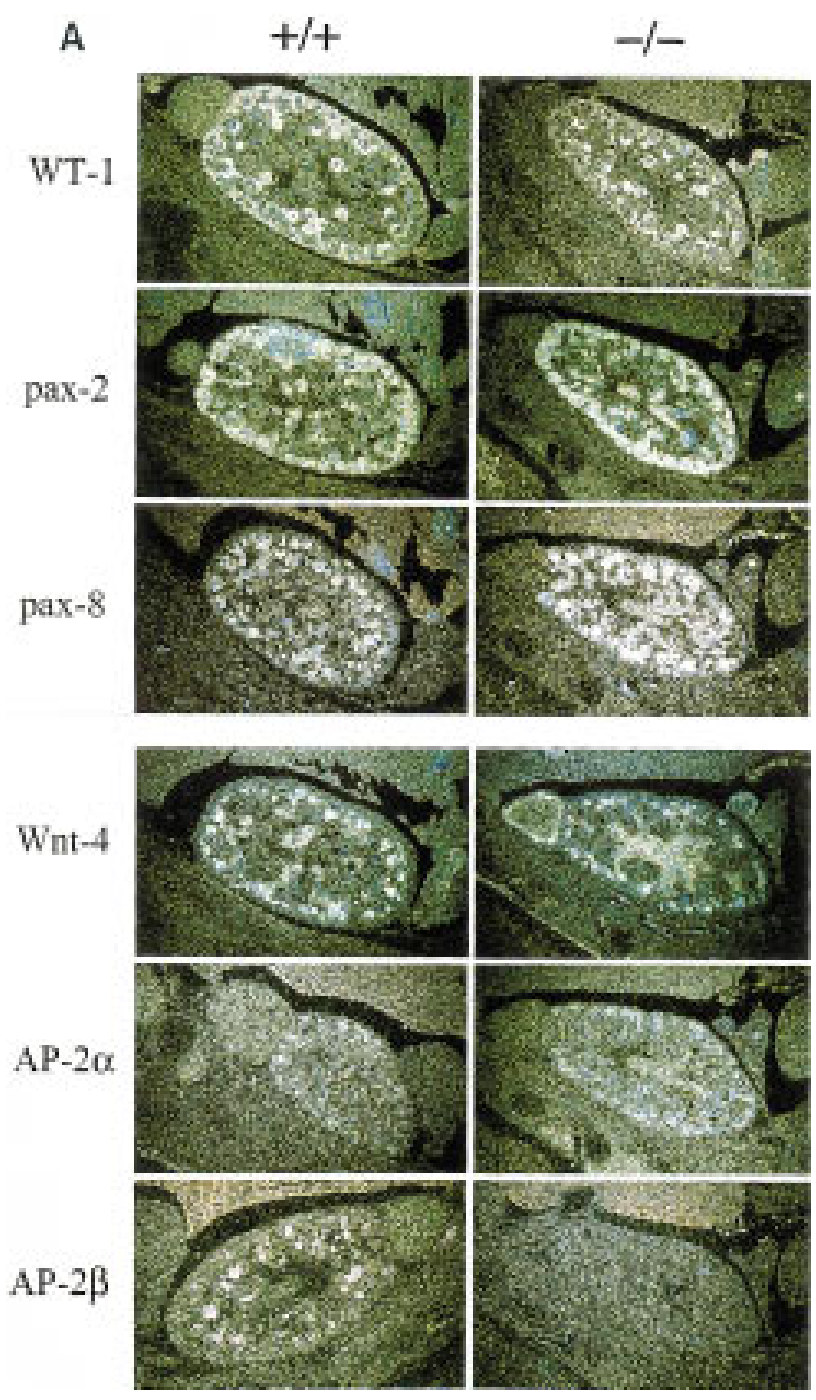

(CM V)-lacZ control plasmid we further determined that $>50 \%$ of PA-1 clone 1 cells expressed high levels of the control gene $24 \mathrm{hr}$ after transient transfection by lipofectamine (data not shown). Eight hours after transfection with human c-myc, AP- $2 \alpha$ or AP- $2 \beta$ expression plasmid apoptosis was provoked by culturing cells for $24 \mathrm{hr}$ under conditions of low growth factor supply [1\% fetal calf serum (FCS)]. Then release of nucleosomes into the tissue culture supernatant was determined using a commercially available ELISA. Results shown in Figure 8 demonstrate that the expression of c-myc in clone 1 cells results in a dramatic increase of nucleosome release exceeding the linear range of ELISA measurements. $\mathrm{N}$ ucleosome release was completely suppressed by cotransfection of equal amounts of A P- $2 \alpha$ or AP- $2 \beta$ expression plasmids. Consistently, the subline clone 1-911A harboring a stably transfected SV 40-AP-2 $\alpha$ expression plasmid was entirely resistant to the effect of transiently transfected c-myc with respect to nucl ear fragmentation and nucleosome rel ease. Identical data were obtained using murine $\mathrm{NIH}-3 \mathrm{~T} 3$ fibroblasts (data not shown).

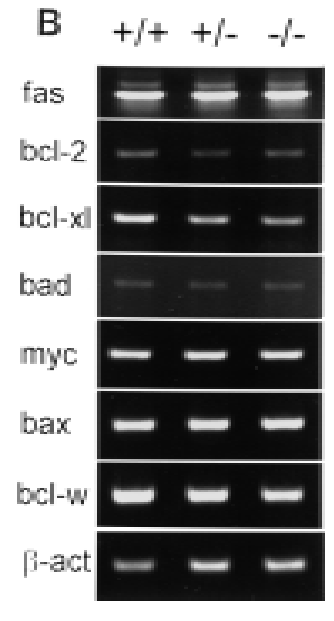

Figure 7. (A) Expression of WT-1, pax, wnt-4, and AP-2 genes in wild-type $(+t+)$ and AP-2 $\beta$-deficient mice $(-t-)$. (Left) In situ hybridization in kidney sections of wild-type E15.5 embryos; (right) hybridization in kidney sections from $-1-$ embryos. The specificity of all reactions was controlled by performing hybridization with sense probes under identical conditions (data not shown). (B) RT-PCR amplification of pro- and antiapoptotic genes. Two micrograms of RNA obtained from microdissected kidneys was amplified by 30 PCR cycles (except for 20 cycles in the case of $\beta$-actin) and separated on a $2 \%$ agarose gel.

In conclusion, these results point to a novel molecular function of AP-2 transcription factors in negatively regulating myc-induced cell death.

\section{Analyses of the AP- $2 \beta$ gene in ARPKD patients}

The morphology of collecting duct-type cysts and distal tubular enlargement in kidneys with an overall preserved architecture is reminiscent of ARPKD occurring in humans. Moreover, AP- $2 \beta$ mRN A is expressed during embryonic development in the structures that are beli eved to be the origin of cyst formation in these patients. We have therefore addressed the question of whether AP$2 \beta$ is a candidate gene for ARPKD. By performing fluorescence in situ hybridization (FISH) in metaphase chromosomes, the genomic position of the human gene was determined on chromosome 6p12-p21.1 (data not shown), which is consistent with results from a previous study (Williamson et al. 1996). Interestingly, the ARPKD mutation has been mapped previously to the same regi on (Zerres et al. 1994). 


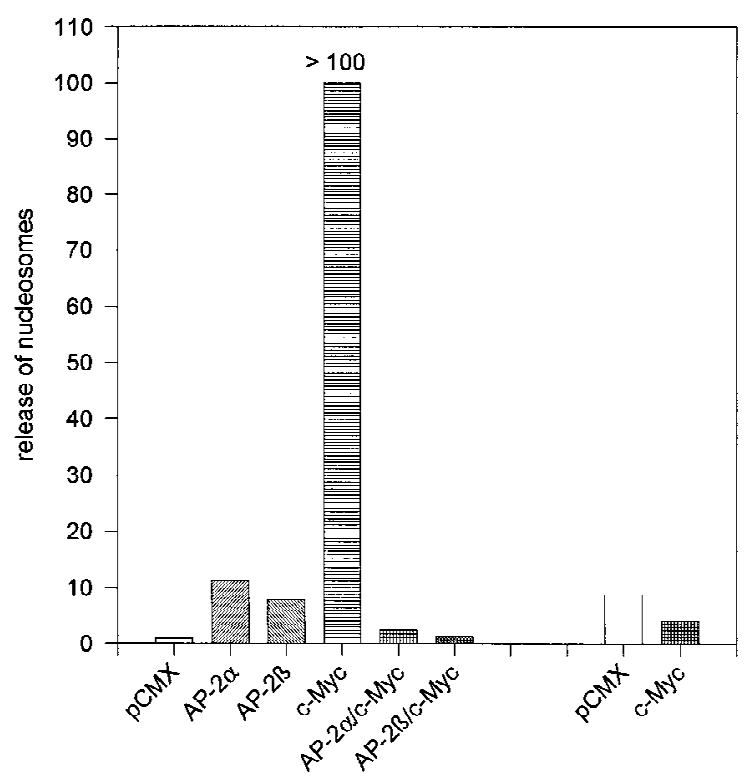

clone1

clone1-911A

Figure 8. N egative regulation of c-myc-induced cell death by AP-2. PA-1 cells were transiently transfected with $1 \mu \mathrm{g}$ of the empty $\mathrm{pCMX}$ vector or $\mathrm{pCMX}$ vectors containing human $\mathrm{AP}$ $2 \alpha$, AP- $2 \beta$, or c-myc expression cassettes. Rel ease of fragmented DN A (nucleosomes) into the tissue culture supernatant after 36 hr growth in $1 \%$ FCS is shown on they-axis. Figures are derived from two independent experiments with four parallel sets each. Transfections into wild-type PA-1 clone 1 cells are shown at the left; transfections into a subline stably harboring a stably transfected AP-2 $\alpha$ expression plasmid (clone 1-911A) at the right.

N ext, we performed sequencing analyses in 20 unre lated ARPKD patients and 10 controls. All seven AP- $2 \beta$ exons were amplified by PCR using primers within flanking intron regions (listed in Table 2). Exon 2 was too large to be amplified and sequenced reliably by a single reaction, therefore, two overlapping PCR reactions were performed in this case. The entire sequence of all eight PCR reactions covering the seven exons, including the splice sites, was determined, but no mutation in the coding regions was identified. In one-third of the samples anal yzed we observed a 1-bp polymorphism 68 bases upstream of exon 1 (7591 G $\rightarrow$ A). Additionally, $\sim 50 \%$ of all samples reveal ed a variation close to the $3^{\prime}$ spl ice site of exon 2, which includes a tetranucl eotide repeat of CAAA four or five times, between nucleic acid residues 12593 and 12612. These polymorphisms were analyzed further by PCR/SSCP in an enlarged group of 40 patients and controls, respectively, and detected at the same frequency in the ARPKD patients and in controls (data not shown).

To exclude the AP- $2 \beta$ gene as a candi date for ARPKD, we determined intragenic polymorphisms suitable for linkage analyses in ARPKD families. Two polymorphic loci were identified, a diallelic one within intron 3 between nucleic residues 22252 and 22281 (AAAAAC) $n=5-6$ and one with five alleles within intron 2 between nucleic acid residues 15285 and $15320(\mathrm{GC})_{\mathrm{n}=20} /(\mathrm{GT})_{\mathrm{n}=8}$.

In a total of 102 ARPKD families, that have been studied previously (Zerres et al. 1996), linkage analyses were performed with these two markers. In this preliminary set of families, including eight key families with recombination events in the ARPKD region, no separation of the AP- $2 \beta$ and ARPKD genes was identified (data not shown). However, in an expanded search with six American key recombinant families, one recombination of AP$2 \beta$ with respect to the ARPKD gene was observed, mapping the gene distal to the ARPKD gene (Fig. 9). Taken together, these data indicate that the AP- $2 \beta$ gene is linked very closely to the ARPKD locus but not mutated in ARPKD patients.

Table 2. Primers used for PCR amplification and sequencing the human AP-2 $\beta$ gene exons

\begin{tabular}{|c|c|c|c|c|}
\hline \multicolumn{2}{|c|}{ Exon } & \multirow{2}{*}{\multicolumn{2}{|c|}{ Primer sequence $5^{\prime} \rightarrow 3^{\prime}$}} & \multirow[b]{2}{*}{ Position of primers } \\
\hline no. & size (bp) & & & \\
\hline \multirow[t]{2}{*}{1} & 48 & up & G A G A C A A C A G A T A T A A G T T G C G & 7497-7518 \\
\hline & & down & C A T T T G G G G T A T C A GA A G C T C & $7783-7762$ \\
\hline \multirow[t]{4}{*}{2} & 453 & up & G C C G G GCT TCTC CA T T T G T CA C & $12000-12021$ \\
\hline & & down & $C \subset G T T G C \subset C \subset \subset A G G G A T G T T G C$ & $12373-12352$ \\
\hline & & & $C \subset T A \subset \subset A \subset \subset A G A G \subset \subset A G G A \subset \subset C$ & $12279-12300$ \\
\hline & & down & C C C C C C C T C C A G A A G C A T T C C T & $12649-12628$ \\
\hline \multirow[t]{2}{*}{3} & 63 & & G A G T A A A T T T C A T T C T C T A T G T C & 17178-17200 \\
\hline & & down & $C A$ A A T A A T GA A T T C C C C CA A A G T G & 17487-17464 \\
\hline \multirow[t]{2}{*}{4} & 222 & up & C A T T C T A T C A G C C G G T C A T C A G & 24449-24471 \\
\hline & & down & T G G A A C C T T C T C C T C A C T G T C C & 24834-24813 \\
\hline \multirow[t]{2}{*}{5} & 117 & up & G C T A A G T C T A A A C T T T G T T T C A G G A & $26627-26650$ \\
\hline & & down & C A T G A A A T G T G T T A A A A T G T C A G C C & 26895-26871 \\
\hline \multirow[t]{2}{*}{6} & 144 & & A A A G C T G A C A A G G G A $T$ G T C T C C & 28798-28821 \\
\hline & & down & $T$ T A G G T C TA G A C A A C C T C T G G C & $29136-29114$ \\
\hline \multirow[t]{2}{*}{7} & 300 & & G A G C G T C T C C T T T C T A A T G C C & 31745-31765 \\
\hline & & down & T T A C T A C C T G G G C C T T C C C C A & $32084-32065$ \\
\hline
\end{tabular}

Positions indicate nucleic acid residues as submitted to the EM BL data library (accession no. Y 09912). 


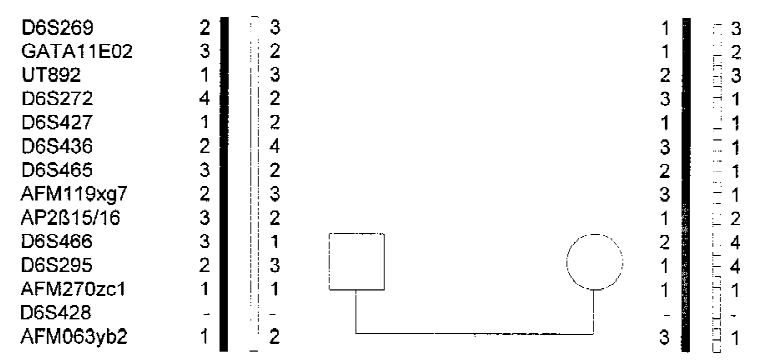

\begin{tabular}{|c|c|c|c|c|c|c|c|}
\hline & & & & & & & 2 \\
\hline UT892 & . & . & 3 & $=3$ & 1 & -2 & 1 \\
\hline D6S272 & 4 & 3 & 2 & 1 & 4 & 1 & 4 \\
\hline D6S427 & 1 & 1 & 2 & $\stackrel{-1}{-1}$ & 1 & 1 & 1 \\
\hline D6S436 & 2 & 3 & 4 & j 1 & 2 & $=1$ & 2 \\
\hline D6S465 & 3 & 2 & 2 & 1 & 3 & $=1$ & 3 \\
\hline AFM119xg7 & 2 & 3 & 3 & 1 & 2 & 1 & 2 \\
\hline $\mathrm{AP} 2 ß 15 / 16$ & - & - & 2 & 22 & 3 & 2 & 3 \\
\hline D6S466 & 3 & 2 & 1 & $\Xi 4$ & 3 & 4 & 3 \\
\hline D6S295 & 2 & 1 & 3 & -4 & 2 & 4 & 2 \\
\hline AFM $270 \mathrm{zc} 1$ & - & - & 1 & 1 & 1 & $\div 1$ & 1 \\
\hline D6S428 & - & & - & $\therefore-$ & - & $E$ & - \\
\hline AFM063yb2 & & & 2 & -1 & 1 & 1 & 1 \\
\hline
\end{tabular}

Figure 9. Haplotype analysis revealing recombination of AP$2 \beta$ and the ARPKD gene locus. Relative positions of polymorphic loci are indicated according to the physical map determined by the ARPKD Consortium (Lens et al. 1997).

\section{Discussion}

In this study we have generated AP- $2 \beta$-null mice by introducing a neo cassette into the fourth exon. Disruption of AP- $2 \beta$ revealed its essential role in normal kidney development, particularly in maintenance of differentiated renal epithelia. Despite widespread embryonic expression of AP- $2 \beta$ in many embryonic tissues, including premigratory and migrating neural crest cells, neural tube derivatives, surface ectoderm, and kidney (M oser et al. 1995, 1997), A P-2 $\beta-1-$ mice complete embryonic development and show no abnormalities other than renal mal formation.

AP- $2 \alpha$ null mice have been analyzed recently, revealingsevere defects of cranial closure in the anterior neural tube and the facial neuroectoderm (Schorle et al. 1996; Zhang et al. 1996). Comparing our results with the phenotype of AP-2 $\alpha$-deficient mice leads to the conclusion that functions of the two genes during embryonic development differ considerably, even though both genes are highly homologous and are expressed during embryonic development with partially overlapping spatial and temporal patterns. Interestingly, AP-2 $\alpha$-null mice reveal significant cell loss in neural structures, including cranial ganglia, raising the possibility that on a molecular level both genes may be key factors involved in suppression of apoptotic cell death.

A poptosis and polycystic kidney disease in AP- $2 \beta-1-$ mice

Our studies defining a role of AP- $2 \beta$ in regulation of re- nal apoptotic cell death have further substantiated a function of apoptosis in renal cyst development. Results from in situ hybridizations to WT-1, pax2, pax-8, and wnt- 4 mRN As indicate that AP- $2 \beta$ mice complete the full embryonic program of renal development, including ureteric bud sprouting, induction of mesenchymal-epithelial cell conversion, and glomerular and tubular cell differentiation. However, at the end of embronic development, epithelia in the medullary region of AP- $2 \beta$-deficient mice undergo apoptosis preceded by down-regulation of antiapoptotic genes of the bcl gene family. These results suggest an essential role of AP- $2 \beta$ in downregulating apoptosis after embryonic development has been completed. Epithelia in the distal tubuli, Henle's loops, and the collecting duct system are indispensable for water retention and regulation of electrolyte homeostasis; therefore, AP-2 $\beta-1-$ mice die shortly after birth.

Our results from transient transfection studies further define a novel function of AP-2 in controlling myc-induced programmed cell death. These data strongly suggest that the occurrence of enhanced apoptosis seen in the kidneys of A P-2 $\beta$-deficient mice results from uncontrolled myc function on a molecular level. Whereas only a slight increase in the apoptotic death rate of renal epithelia was observed between E13.5 and E18.5, massive death occurred around birth at a time when growth factor supply was limited (Coles et al. 1993). Consistently, we detected reduced expression of the antiapoptotic genes $b c l 2, b c l-w$, and $b c l-X_{L}$, which are known to be expressed in renal epithelia and to control critically cell survival (Veis et al. 1993; Gonzalez-Garcia et al. 1994; Sorenson et al. 1995). Furthermore, it has been shown that bcl-2 can override myc-induced cell death (Bissonnette et al. 1992).

Large-scale programmed cell death has been well documented in devel oping rat kidney and was shown to occur in both the nephrogenic region and medullary papilla (Coles et al. 1993). Based on these studies it has been estimated that $50 \%$ or more of renal cells die during normal development. The regions of apoptotic cell death in AP-2 $\beta$ mutant mice overlap precisely with the expression pattern of AP- $2 \beta$ mRNA in distal tubular and collecting duct epithelia. Thus, A P- $2 \beta$ seems to be essential for survival of epithelial cells in the renal medulla. The fact that AP- $2 \beta$ mRNA is expressed al so at high levels in kidneys of adult mice suggests further that the function of AP-2 $\beta$ for renal epithelial cell survival is indispensable throughout adulthood. It remains to be investigated whether A P- $2 \beta$ plays a role in pathological conditions that involve damage and regeneration of renal epithelia. Interestingly, we have observed that significant overexpression of AP-2 mRN As occurs in a subset of renal cell cancers ( $M$. M oser, unpubl.). Because significantly enhanced levels of AP-2 expression have also been described in breast cancer cells versus normal mammary epithelia (Bosher et al. 1995), it is tempting to speculate that AP-2 genes may protect proliferating cells from myc-induced apoptotic cell death under conditions of limiting growth factor supply.

Our studies establish defects in regulating cell death as 
a significant disease mechanism in renal cyst formation. Consistently, transgenic and knockout studies of c-myc and bcl-2 have al so reveal ed cyst formation in the respective mice (Trudel et al. 1991; Veis et al. 1993). Thus, cyst formation may be a downstream pathophysiological event resulting from alterations of different genes regulating cell death in renal epithelia. Even more intriguing$l y$, it has been shown recently that transcriptional regulation of c-myc target genes is under negative control by AP-2 (Gaubatz et al. 1995). Both AP- $2 \alpha$ and AP-2 $\beta$ proteins form a ternary complex with $\mathrm{myc} / \mathrm{max}$ heterodimers to prevent DNA binding to canonical E-box elements. The partial overlap in pathology of c-mycoverexpressing transgenics and AP- $2 \beta$ knockouts with respect to renal cyst formation raises the possibility that suppression of apoptotic cell death by AP-2 involves downstream transcriptional targets of the c-myc protooncogene.

\section{AP- $2 \beta$ and ARPKD}

Recently, significant progress has been made revealing the genetic basis of ARPKD in humans. Clinical and genetic analyses of different families have provided evidence that the severe and mild forms of the disease are caused by different mutations of the same locus but not by mutations of different genes. Furthermore, linkage analyses of polymorphic markers in recombinant families have mapped the ARPKD gene within a region of chromosome 6p21-cen (centromere) (Zerres et al. 1994). In the severe form, patients often die after birth, revealing bilaterally enlarged kidneys with general ized dilatation and cysts of the collecting duct (Zerres et al. 1996). The disease is invariably associated with congenital hepatic fibrosis attributable to biliary duct mal formations; however, the degree of liver pathology can vary considerably. Histopathological findings in AP- $2 \beta-1-$ mice show striking similarity with features of ARPKD, but they are cl early not identical. M ost importantly, we have not been able to detect any failure in biliary duct formation in either embryonic or postnatal livers in AP-2 $\beta$ deficient mice. On a molecular level, we have not detected any AP- $2 \beta$ mutations in 20 different ARPKD patients. However, linkage anal yses reveal that the gene is in close proximity to the ARPKD gene, making the identified polymorphic markers useful for diagnostic purposes. Ongoing studies will address the question of whether AP-2 $\beta$ expression is modified as a downstream target of the ARPKD mutation.

\section{Materials and methods}

Isolation of murine and human AP- $2 \beta$ genes and FISH

Plaques of commercially available human and murine SVJ 129 genomic libraries (Lambda FIXII, Stratagene, Heidelberg, Germany) $\left(5 \times 10^{5}\right)$ were screened with AP- $2 \beta$ CDN A probes using standard procedures (Sambrook et al. 1989). Cycle sequencing was performed using an automatic DNA sequencer (Applied Biosystems, Boulder, CO). For FISH in human metaphase chromosomes, two Sall fragments covering 10 and $8 \mathrm{~kb}$ at the $5^{\prime}$ region of the human AP- $2 \beta$ gene were label ed with bio-dUTP by nick translation and hybridized as described previously (Lichter et al. 1990).

Construction of the AP- $2 \beta$ targeting vector and generation of gene-disrupted mice

A clone that contained $10 \mathrm{~kb}$ of murine SVJ129 genomic DN A spanning exons 3,4 , and 5 was used to insert a PGK-neo cassette into the Smal site of exon 4. Linearized plasmid DNA $(75 \mu \mathrm{g})$ was el ectroporated into $5 \times 10^{7} \mathrm{R} 1 \mathrm{ES}$ cells suspended in phosphate-buffered saline. Transfection and culture conditions of ES cells have been described recently (Pfeifer et al. 1996). Briefly, ES cells were cultured on irradiated mouse embryonic fibroblasts in the presence of leukemia inhibitory factor (GIBCO BRL, Gaithersburg, MD) and selected with $400 \mu \mathrm{g} / \mathrm{ml}$ of G418 (GIBCO BRL); then 360 neo-resistant clones were picked, expanded, and analyzed from genomic EcoRI-digested DNA by Southern blot. An external probe comprising a 1-kb genomic EcoRI-Smal fragment of the AP- $2 \beta$ gene (see Fig. 1B) was used to identify the $13-\mathrm{kb}$ wild-type allele and the $8.5-\mathrm{kb}$ mutated alIele.

Two different ES cell clones with the targeted AP-2 $\beta$ allele were thawed 3 days prior to injection, and 10 cells each were microinjected into C57B6 blastocysts that had been harvested at $2.5 \mathrm{dpc}$. Microinjected blastocycts were reimplanted on the same day into 3.5-day pseudopregnant females. Male chimeras were mated with C57B6 females.

In situ hybridization, Western blot, propidium iodide staining of pyknotic nuclei, and TU NEL assay and cell death detection

At the appropriate time, pregnant mice were perfused with $4 \%$ fresh paraformal dehyde/ $0.5 \%$ glutaral dehyde in $0.15 \mathrm{~m}$ cacodylate buffer at $\mathrm{pH}$ 7.4. The embryos were dissected and postfixed for $2 \mathrm{hr}$. In situ hybridization of ${ }^{35} \mathrm{~S}$-labeled CRNA probes in paraffin-embedded tissue sections has been described in detail previously (M oser et al. 1995). Two parallel tissue sections were mounted on each slide, and both antisense and sense (as control) RN A probes were reacted to these sections under identical conditions.

For Western analysis the midbrain of embryos at $18.5 \mathrm{dpc}$ was microdissected and extracted with $2 \times$ Laemmli's buffer. Lysate (150 mg/lane) was loaded, separated on $12.5 \%$ SDS-polyacrylamide gels, and transferred onto nitrocellulose. Blots were reacted with 1:8000 dilution of a commercially available rabbit polyclonal AP-2 antiserum (Santa Cruz Biotech, Santa Cruz, CA) and developed using a chemiluminiscence reaction kit (ECL, Amersham, Braunschweig, Germany).

Nuclear pyknosis was visualized with propidium iodide (Coles et al. 1993). N ewborn mice were fixed for $24 \mathrm{hr}$ in 10\% phosphate-buffered formalin and embedded in paraffin. Dewaxed tissue slides were rehydrated, stained with $4 \mu \mathrm{g} / \mathrm{ml}$ of propidium iodide, and $100 \mu \mathrm{g} / \mathrm{ml}$ of RN ase A in PBS for $30 \mathrm{~min}$ at $37^{\circ} \mathrm{C}$; slides were then washed and analyzed on a fluorescence microscope.

Labeling of fragmented nuclear DNA with terminal deoxynucleotide transferase ( $T d t)$ was performed essentially as described (Gavrieli et al. 1992). Briefly, rehydrated sections from $10 \%$ formalin-fixed and paraffin-embedded tissues were incubated with $10-40 \mu \mathrm{g} / \mathrm{ml}$ of proteinase $\mathrm{K}$ for $30 \mathrm{~min}$ at $37^{\circ} \mathrm{C}$ and postfixed with $4 \%$ paraformaldehyde for $5 \mathrm{~min}$. Membranes were permeablized with $0.1 \%$ Triton X-100 in $0.1 \mathrm{M} \mathrm{N}$ a-citrate and incubated with TUNEL reagent (Boehringer, Mannheim, Germany), following the manufacturer's instructions. 
For detection of cell death in transiently transfected PA-1 cells, 4 parallel sets of $8 \times 10^{4}$ cells were plated into 12 -well plates and maintained in Dulbecco's modified Eagle's medium (DMEM) supplemented with $10 \%$ FCS (GIBCO BRL, Eggenstein, Germany). Sixteen hours later, $1 \mu \mathrm{g}$ of CMV-AP- $2 \alpha$, CMV-AP-2 $\beta$, or CMV-c-myc plasmid was transfected using lipofectamine (GIBCO BRL). Eight hours after transfection the medium was changed to DMEM/1\% FCS, and the tissue culture supernatant was harvested $36 \mathrm{hr}$ later. Rel ease of nucleosomes was quantitated using the anti-histone-based commercially available Cell Death Detection ELISA ${ }^{\text {Plus }}$ (Boehringer, Mannheim, Germany) following the manufacturer's instructions precisely.

\section{RT-PCR amplification}

Total RNA was prepared from microdissected kidneys of mice at E18.5. Reverse transcription was performed using $2 \mu \mathrm{g}$ of total RN A as described previously (M oser et al. 1995). Ten percent of the reaction $(3 \mu \mathrm{l})$ was added to $1 \mu \mathrm{l}$ of $10 \mathrm{~mm}$ dNTP, $5 \mu \mathrm{l}$ of $10 \times$ PCR buffer, $2 \mu$ of sense and antisense primer each ( 25 pmoles/ $\mu \mathrm{l}), 0.5 \mu \mathrm{l}$ of Taq polymerase (Boehringer, Mannheim, Germany), and $36.5 \mu$ of $\mathrm{H}_{2} \mathrm{O}$. Thirty and $32 \mathrm{PCR}$ cycles, respectively, were performed at the following profile: $1 \mathrm{~min}$ at $94^{\circ} \mathrm{C}, 1$ $\min$ at $62^{\circ} \mathrm{C}$, and $1.5 \mathrm{~min}$ at $72^{\circ} \mathrm{C}$. For $\beta$-actin amplification only 20 cycles were performed. PCR primers for mouse are indicated from 5' to 3': fas sense, ATGCTGTGGATCTGGGCTGTCCT; fas antisense, GCATAATGGTTCTTGTCCATG; bcl-2 sense, CTTGACAGAAGATCATGCCGTCC; bcl-2 antisense, GTATGTACTTCATCACGATCTCC; c-myc sense, CTCCTCGAGCTGTTTGAAGGC; c-myc antisense, TGAAGGTCTCGTCGTCAGGATC; bad sense, CTGGAGGACTTATCAGCCGAAG; bad antisense, ATGTGGAGCAGAAGATCACTGG; bcl-x sense, GAGTTTGAACTGCGGTACCGG; bcl-x antisense, TTCCGACTGAAGAGTGAGCCC; bcl-w sense, ATGGCGACCCCAGCCTCAACC; bcl-w antisense, GTATAGAGCTGTGAACTCCGC; bax sense, GAGACACCTGAGCTGACCTTGG; bax antisense, TCAGCCCATCTTCTTCCAGATGG; $\beta$-actin sense, TGGAATCCTGTGGCATCCATGAAAC; $\beta$-actin antisense, TAAAACGCAGCTCAGTAACAGTCCG.

\section{Sequence and haplotype analyses of ARPKD families}

For sequence analysis AP- $2 \beta$ exons were amplified by PCR from peripheral blood DNA using the primer pairs listed in Table 2. PCR conditions were $35 \mathrm{cycles}$ of $40 \mathrm{sec}$ at $95^{\circ} \mathrm{C}, 60 \mathrm{sec}$ at $65^{\circ} \mathrm{C}$, and $60 \mathrm{sec}$ at $72^{\circ} \mathrm{C}$. PCR reaction products were gel-analyzed, then purified by precipitation with polyethylene glycol 8000, and sequenced with $5 \mathrm{~nm}$ of each PCR primer using a cycle sequencing Taq polymerase protocol (Perkin Elmer, Norwalk, CT). All PCR products were sequenced entirely on both strands. A panel of 20 patients was analyzed with different clinical manifestations ranging from perinatally lethal to mild forms of adulthood (Zerres et al. 1996).

To amplify intragenic polymorphic repeats located in intron 3 (22252-22281) and intron 2 (15285-15320), respectively, the following two primer pairs were designed and used under the same PCR conditions as indicated above: 5'-CAAAGCACATCTTCTGACATTGTCC-3' (matching bases 22208-22232) and 5'-TATACATTATCACCTGCATACCCCC-3' (22325-22349); 5'AGCAAATCGCTGTTTGGGTTCTGGG-3' (15232-15256) and 5'-CAAACTAAACAAATCCCAAACTAGGTG-3' (1539815423). N ucleic acid residues are indicated with respect to the complete human genomic AP- $2 \beta$ sequence as submitted to the EMBL data library (accession no. Y 09912).
Hapl otype analyses were performed in a panel of 110 families manifesting with the severe form of ARPKD (Zerres et al. 1996).

\section{Acknowledgments}

This work was supported by grants from the Deutsche Forschungsgemeinschaft to K.Z., R.B., and R.F.; from the Wilhelm Sander-Stiftung to R.B.; and from the Hermann and Lilly Schilling Stiftung to R.F. We thank Drs. Peter Gruss, Andrew M CM ahon, and Helen Hurst for pax-2, pax-8, wnt-4, and AP- $2 \gamma$ plasmids; Rudi Balling for helpful discussions, and the entire Regensburg Medical School photo laboratory for the photographical artwork.

The publication costs of this article were defrayed in part by payment of page charges. This article must therefore be hereby marked "advertisement" in accordance with 18 USC section 1734 solely to indicate this fact.

\section{References}

Bauer, R., A. Pscherer, A. Imhof, M. Moser, H. Kopp, S. Seegers, M. Kerscher, M.A. Tainsky, F. Hofstaedter, and R. Buettner. 1994. The genomic structure of the human AP-2 gene. Nucleic Acids Res. 22: 1413-1420.

Bissonnette, R.P., F. Echeverri, A. Mahboubi, and D.R. Green. 1992. A poptotic cell death induced by c-myc is inhibited by bcl-2. Nature 359: 552-554.

Bosher, J.M., T. Williams, and H.C. Hurst. 1995. The developmentally regulated transcription factor AP-2 is involved in c-erbB-2 overexpression in human mammary carcinoma. Proc. Natl. Acad. Sci. 92: 744-747.

Chazaud, C., M. Oulad-A bdel ghani, P. Bouillet, D. Decimo, P. Chambon, and P. Dolle. 1996. AP-2.2, a novel gene related to AP-2, is expressed in the forebrain, limbs and face during mouse embryogenesis. Mech. Dev. 54: 83-94.

Coles, H.S.R., J.F. Burne, and M.C. Raff. 1993. Large-scale normal cell death in the devel oping rat kidney and its reduction by epidermal growth factor. Development 118: 777-784.

Gaubatz, S., A. Imhof, R. Dosch, O. Werner, P. Mitchell, R. Buettner, and M. Eilers. 1995. Transcription factor AP-2 negatively regulates gene activation by myc. EMBO J. 14: 1508-1519.

Gavrieli, Y., Y. Sherman, and S.A. Ben-Sasson. 1992. Identification of programmed cell death in situ via specific labeling of nuclear DN A fragmentation. J. Cell Biol. 119: 493-501.

Gonzalez-Garcia, M., R. Perez-Ballestro, L. Ding, L. Duan, L.H. Boise, C.B. Thompson, and G. N unez. 1994. Bcl-XL is the major bcl-X mRNA form expressed during murine development and ist product localizes to mitochondria. Development 120: 3033-3042.

Kannan, P., R. Buettner, P.J. Chiao, S.O. Yim, M. Sarkiss, and M.A. Tainsky. 1994. N-ras oncogene causes AP-2 transcriptional self-interference, which leads to transformation. Genes \& Dev. 8: 1258-1269.

Lens, X.M., L.F. Onuchic, G. Wu, T. Hayashi, M. Daoust, T. Mochizuki, L.B. Santarina, J.M. Stockwin, G. Muecher, J. Becher, W.E. Sweeny, E.D. Avner, L. Guay-Woodford, K. Zerres, S. Somlo, and G.G. Germino. 1997. An integrated genetic and physical map of the autosomal recessive polycystic kidney disease region. Genomics 41: 463-466.

Lichter, P., C.J. Tang, K. Call, G. Hermanson, G.A. Evans, D. Housman, and D.C. Ward. 1990. High resolution mapping of human chromosome 11 by in situ hybridization with cosmid 
clones. Science 247: 64-69.

Mitchell, P.J., P.M. Timmons, J.M. Hebert, P.W. Rigby, and R. Tjian. 1991. Transcription factor AP-2 is expressed in neural crest lineages during mouse embryogenesis. Genes \& Dev. 5: 105-119.

Moser, M., A. Pscherer, A. Imhof, R. Bauer, M. Kerscher, W. Amsel gruber, F. Sinowatz, F. Hofstaedter, R. Schüle, and R. Buettner. 1995. M olecular cloning and characterization of a second AP-2 transcription activator gene, AP-2 $\beta$. Development 121: 2779-2788.

Moser, M., J. Rüschof, and R. Buettner. 1997. Comparative analysis of AP- $2 \alpha$ and AP-2 $\beta$ gene expression during murine embryogenesis. Dev. Dynam. 208: 115-124.

Oulad-A bdelghani, M., P. Bouillet, C. Chazaud, P. Dollé, and P. Chambon. 1996. AP-2.2: A novel AP-2 related transcription factor induced by retinoic acid during differentiation of P19 embryonal carcinoma cells. Exp. Cell Res. 225: 338-347.

Pfeifer, A., A. Aszódi, U. Seidler, P. Ruth, F. Hofmann, and R. Fässler. 1996. Intestinal secretory defects and dwarfism in mice lacking CGMP-dependent protein kinase II. Science 274: 2082-2086.

Sambrook, J., E.F. Fritsch, and T. Maniatis. 1989. Molecular cloning: A laboratory manual, 2nd ed. Cold Spring Harbor Laboratory Press, Cold Spring Harbor, NY.

Schorle, H., P. M eier, M. Buchert, R. Jaenisch, and P.J. M itchell. 1996. Transcription factor AP-2 essential for cranial closure and craniofacial development. Nature 381: 235-238.

Sorenson, C.M., S.A. Rogers, S.J. Korsmeyer, and M.R. Hammerman. 1995. Fulminant metanephric apoptosis and abnormal kidney development in bcl-2-deficient mice. Am. J. Physiol. F73-F81.

Trudel, M., V. D'Agati, and F. Costantini. 1991. c-myc as an inducer of polycystic kidney disease in transgenic mice. Kidney Int. 39: 665-671.

Veis, D.J., C.M. Sorenson, J.R. Shutter, and S.J. Korsmeyer. 1993. Bcl-2-deficient mice demonstrate fulminant Iymphoid apoptosis, polycystic kidneys, and hypopigmented hair. Cell 75: 229-240.

Williams, T. and R. Tjian. 1991a. Analysis of the DN A-binding and activation properties of the human transcription factor AP-2. Genes \& Dev. 5: 670-682.

Williams, T. and R. Tjian. 1991b. Characterization of a dimerization motif in AP-2 and its function in heterologous DN Abinding proteins. Science 251: 1067-1071.

Williams, T., A. Admon, B. Lüscher, and R. Tjian. 1988. Cloning and expression of AP-2, a cell-type-specific transcription factor that activates inducible enhancer elements. Genes \& Dev. 2: 1557-1569.

Williamson, J.A., J.M. Bosher, A. Skinner, D. Sheer, T. Williams, and C. Hurst. 1996. Chromosomal mapping of the human and mouse homologues of two new members of the AP-2 family of transcription factors. Genomics 35: 262-264.

Zerres, K., G. M ücher, L. Bachner, G. Deschennes, T. Eggermann, H. Kääriäinen, M. Knapp, T. Lennert, J. M issel witz, K.E. von Mühlendahl, H.P.H. N eumann, Y. Pirson, S. Rudnik-Schöneborn, V. Steinbicker, B. Wirth, and K. Schärer. 1994. Mapping of the gene for autosomal recessive polycystic kidney disease (ARPKD) to chromosome 6p21-cen. Nature Genet. 7: 429-432.

Zerres, K., S. Rudnik-Schöneborn, F. Deget, U. Holtkamp, J. Brodehl, J. Geisert, and K. Schärer. 1996. Autosomal recessive polycystic kidney disease in 115 children: Clinical pre sentation, course and influence of gender. Acta Paediatr. 85: 437-445.

Zhang, J., S. Hagopian-Donal dson, G. Serbedzija, J. Elsemore, D. Plehn-Dujowich, A.P. McMahon, R.A. Flavell, and T. Willi- ams. 1996. Neural tube, skeletal and body wall defects in mice lacking transcription factor AP-2. Nature 381: 238241. 


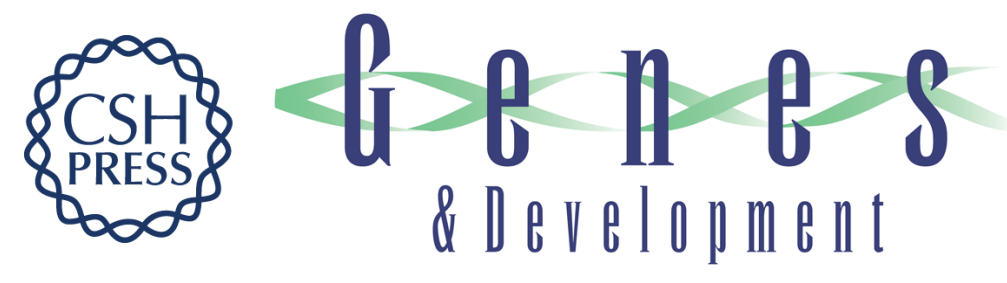

\section{Enhanced apoptotic cell death of renal epithelial cells in mice lacking transcription factor AP-2 $\beta$}

Markus Moser, Armin Pscherer, Christina Roth, et al.

Genes Dev. 1997, 11:

Access the most recent version at doi:10.1101/gad.11.15.1938

References This article cites 26 articles, 12 of which can be accessed free at: http://genesdev.cshlp.org/content/11/15/1938.full.html\#ref-list-1

License

Email Alerting

Service

Receive free email alerts when new articles cite this article - sign up in the box at the top right corner of the article or click here.

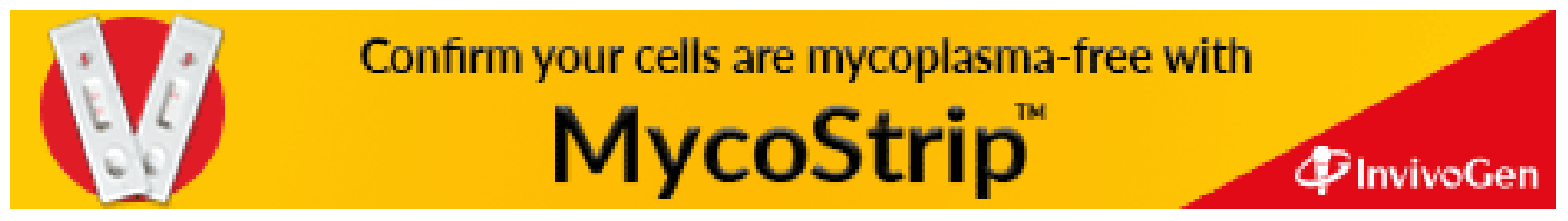

